\title{
Basal melt of the southern Filchner Ice Shelf, Antarctica
}

\author{
Ole Zeising $^{1,2}$, Daniel Steinhage ${ }^{1}$, Keith W. Nicholls ${ }^{3}$, Hugh F. J. Corr ${ }^{3}$, Craig L. Stewart ${ }^{4,5}$, and \\ Angelika Humbert ${ }^{1,2}$ \\ ${ }^{1}$ Alfred-Wegener-Institut Helmholtz-Zentrum für Polar- und Meeresforschung, Bremerhaven, Germany \\ ${ }^{2}$ Department of Geosciences, University of Bremen, Bremen, Germany \\ ${ }^{3}$ British Antarctic Survey, Natural Environment Research Council, Cambridge, UK \\ ${ }^{4}$ Scott Polar Research Institute, University of Cambridge, Cambridge, UK \\ ${ }^{5}$ now at: National Institute of Water and Atmospheric Research, Wellington, New Zealand
}

Correspondence: Ole Zeising (ole.zeising@awi.de)

\begin{abstract}
Basal melt of ice shelves is a key factor governing discharge of ice from the Antarctic Ice Sheet as a result of its effects on buttressing. Here, we use radio echo sounding to determine the spatial variability of the basal melt rate of the southern Filchner Ice Shelf, Antarctica along the inflow of Support Force Glacier. We find moderate melt rates with a maximum of $1.13 \mathrm{~m} \mathrm{a}^{-1}$ about $50 \mathrm{~km}$ downstream of the grounding line. The variability of the melt rates over distances of a few kilometres

5 is low (all but one $<0.15 \mathrm{~m} \mathrm{a}^{-1}$ at $<2 \mathrm{~km}$ distance), indicating that measurements on coarse observational grids are able to yield a representative melt rate distribution. A comparison with remote sensing based melt rates revealed that, for the study area, large differences were due to inaccuracies in the estimation of vertical strain rates from remote sensing velocity fields. These inaccuracies can be overcome by using modern velocity fields.
\end{abstract}

\section{Introduction}

Filchner Ice Shelf (FIS), a West Antarctic ice shelf draining major East Antarctic ice streams (Bailey, Slessor, Recovery and Support Force glaciers) is thought to be vulnerable to a change in its basal mass balance within this century (Hellmer et al., 2012) as a result of the possible penetration of relatively warm, off-shelf waters into the ocean cavity beneath the ice shelf. Subsequent thinning of the ice shelf would reduce its buttressing of inland glaciers, allowing them to speed up and thin, and their grounding lines to retreat landward. If the stress perturbation is sufficiently large then a positive ice-loss feedback may occur as the ice sheet's grounding line retreats across the deepening beds of the tributary ice streams (Schoof, 2012). The current discharge of ice across the grounding line at FIS is $106.3 \pm 5.7 \mathrm{Gta}^{-1}$ (Rignot et al., 2019), which is about $9.6 \%$ of the discharge from East Antarctica, underlining the importance of understanding the current state of the ice shelf for assessing future change in basal melt. In addition, precise melt rates serve as validation for models projecting the future contribution of these ice streams to sea level change.

Basal melt rates can be derived from satellite remote sensing data by solving the ice thickness evolution equation (Rignot et al., 2013; Moholdt et al., 2015; Berger et al., 2017; Adusumilli et al., 2020). Although the Lagrangian approach adopted in recent years (Moholdt et al., 2015) has led to improvements, major uncertainties from various factors remain. Hence, in situ observations of basal melt rates are required for assessing the reliability of remote sensing approaches. This is even more 
https://doi.org/10.5194/tc-2021-230

Preprint. Discussion started: 27 August 2021

(c) Author(s) 2021. CC BY 4.0 License.

\section{(c) (i)}

urgent, as remote sensing-derived basal melt rates are used to construct parameterisations that diagnose basal melt rates from modelled sub-ice shelf ocean conditions. These models are used to project the contribution of Antarctica to sea level change. Significant errors in observed distributions of basal melt rate therefore have a profound effect on the outcome of projections of future sea level rise, such as ISMIP6 (Seroussi et al., 2020), as a result of their effect on the calibration of basal melt rate parametrisations (Jourdain et al., 2020).

In recent years, the use of the phase-sensitive radio echo sounder (pRES) opened new possibilities for the precise determination of basal melt rates. Nicholls et al. (2015) and Stewart et al. (2019) presented basal melt rates from near Ross Island, Ross Ice Shelf, Antarctica, which were derived from 10-days of autonomous pRES (ApRES) measurements, and measurements from 78 stations, time-averaged between 2013 and 2014. Stewart et al. (2019) observed strong seasonal melt rate variability, with values up to $53 \mathrm{ma}^{-1}$ within a five day period in January 2013 and an exponentially reducing mean annual basal melt rate with increasing distance from the calving front, with values up to $7.7 \mathrm{ma}^{-1}$. Vaňková et al. (2020) presented a tidal melt and vertical strain analysis from 17 ApRES records across Filchner-Ronne Ice Shelf. They found the tidal vertical strain to be depth dependent only near the grounding line, with significant tidal melt measurable at some locations. The derived melt rates were used by Bull et al. (2021) to evaluate an ocean model. Marsh et al. (2016) investigated basal melt rates at 25 points at a melt channel near the grounding line of Ross Ice Shelf. They found basal melt rates decreasing from $22 \mathrm{ma}^{-1}$ at the upstream end of the channel to $2.5 \mathrm{ma}^{-1} 40 \mathrm{~km}$ downstream. A strong seasonal variability in melt rate was recorded by Washam et al. (2019) on Petermann Gletscher, Greenland, using an ApRES recording on the flank of a basal melt channel. In Summer 2016, they found extreme melt rates equivalent to $80 \mathrm{ma}^{-1}$ but most of the year the mean basal melt rate ranged from 0 to $10 \mathrm{ma}^{-1}$.

Our survey is focused on the more benign southern part of FIS, which might be more susceptible to the potential inflow of warm waters (Hellmer et al., 2012). Recent observations from hot-water drilled boreholes through Filchner-Ronne Ice Shelf have revealed an interannual change in circulation mode starting in 2017, highlighting the variability in conditions within the sub-ice shelf cavity (Hattermann et al., 2021).

Here, we aim at understanding the magnitude and variation of basal melt over an area extending from the grounding line of Support Force Glacier, as far downstream as was feasible. In austral summer 2015/16, under the framework of the Filchner Ice Shelf Project (FISP), pRES measurements were carried out at a total of 94 locations, and then repeated a year later. The stations were distributed along the central flow line of Support Force Glacier's extension on to FIS and along four crosssections, providing along-flow and across-flow melt rate distributions (Fig. 1). A further transect crossed the entire FIS south of Berkner Island. As far as safety allowed, we extended the profiles along the eastern margin towards the inland ice, to capture an area where gradients in the bathymetry were expected, steering the flow of water masses. With this observational design we intended to measure the large scale distribution of melt rates, but in addition we included more closely spaced stations to detect variations on short spatial scales. In the following, we first introduce the methodology and the data basis. We then present and discuss the derived basal melt rates and compare them with remote sensing data. 


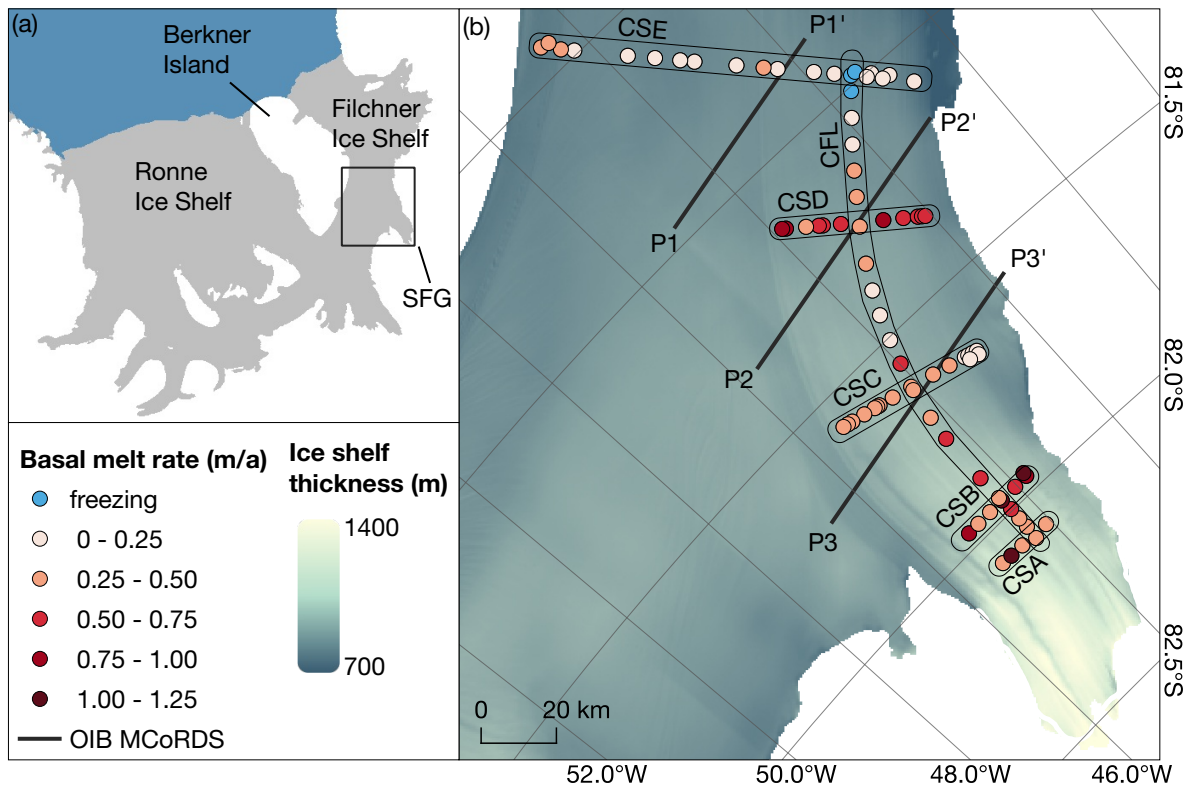

Figure 1. (a) Map of the Ronne and Filchner ice shelves (BedMachine Antarctica (Morlighem, 2020; Morlighem et al., 2020)) with the marked study area (black box) near the Support Force Glacier (SFG). (b) Study area with derived basal melt rates (dots), grouped depending on their location on the Central Flow line (CFL) and five Cross-Sections CSA, CSB, CSC, CSD and CSE. Multi-channel Coherent Radar Depth Sounder (MCoRDS) profiles (P1-P3) flown as part of NASA's Operation IceBridge (OIB) campaign in 2016 (Paden et al., 2014 , updated 2019) are shown by black lines (Echograms are included in the Appendix, Fig. A1). Background colour shows the ice-shelf thickness from BedMachine Antarctica (Morlighem, 2020; Morlighem et al., 2020).

\section{Materials and methods}

Our estimation of basal melt rates is based on measurements using a pRES that is described in detail in Brennan et al. (2014) and Nicholls et al. (2015). The pRES transmits a frequency modulated sweep (chirp) from 200 to $400 \mathrm{MHz}$ over a period of one second. After internal processing, only the difference in frequency between the transmitted and received signals, called the deramped frequency, is saved. Details of the internal processing are given by Brennan et al. (2014). By repeating the measurements after a time period, we are able to track changes in depth of internal reflectors within the ice, and of the basal echo, to a precision of millimetres. This allows the study of firn densification, vertical strain due to ice flow, and the (Lagrangian) change in ice-shelf thickness. Being a Lagrangian measurement, no steady state assumption is required, and the basal melt rate can be separated from the overall change in ice thickness.

Our 94 measurement stations are grouped depending on their location on the Central Flow line (CFL) and five CrossSections (CS) A - E (for location, see Fig. 1). The time period between repeated measurements varied between 323 and 356 days. To improve the signal-to-noise ratio, we recorded 100 chirps at each site. Low correlation chirps were rejected during preprocessing. Those remaining chirps were averaged and then Fourier transformed to yield a complex (amplitude and phase) 
https://doi.org/10.5194/tc-2021-230

Preprint. Discussion started: 27 August 2021

(c) Author(s) 2021. CC BY 4.0 License.

(c) (i)

profile as a function of two-way-travel time. To convert the profile into a function of range we calculated the velocity profile of the electromagnetic wave for each location by estimating the density-depth profile based on Herron and Langway (1980) with accumulation and mean annual temperature from RACMO 2.3/ANT (van Wessem et al., 2014).

Using a procedure similar to that described by Corr et al. (2002) and Jenkins et al. (2006), we aligned the two radar profiles using a $50 \mathrm{~m}$ window below the firn-ice boundary by cross-correlating the amplitude profiles. This provided a datum within the ice column, removing the effects of instrument temperature change, firn densification and snow accumulation and ablation.

The thickness change $\left(\mathrm{D} H_{i} / \mathrm{D} t\right)$ in the solid-ice below the aligned reflector is caused only by the dynamic ice thickness change due to vertical strain $\left(H_{i} \dot{\varepsilon}_{z z}\right)$ and by the basal melt rate $a_{b}$ :

$\frac{\mathrm{D} H_{i}}{\mathrm{D} t}=H_{i} \dot{\varepsilon}_{z z}-a_{b}$,

with $H_{i}$ the solid-ice thickness below the aligned reflector and $\dot{\varepsilon}_{z z}$ the vertical strain rate. In order to determine the vertical strain, the displacement between visits was calculated with a cross-correlation of the amplitude and phase information for each layer deeper than the aligned reflector. Under the plain-strain assumption the vertical strain is constant with depth; a leastsquares method was used to calculate a linear fit of the shift of those layers that exhibited a high correlation value. The gradient of the linear fit is the vertical strain. The change in ice thickness below the aligned reflector is derived from the shift of the basal reflector, which was calculated in the same way as the shift of the internal layers. The largest error in the calculation comes from the alignment of the data because it is based only on the amplitude correlation. The uncertainty in the calculation of the phase shift is closely related to the signal to noise ratio of the reflectors. An additional uncertainty arises from the assumption of a linear strain-depth relation, although this is generally thought reliable for plug flow.

\section{Results}

\subsection{Large scale spatial variability}

Seventy-nine of the 94 measurements were suitable for retrieval of basal melt rates. The main reasons for excluding the other 15 stations are (1) low correlation values in the depth of the firn-ice transition, which made it impossible to align the measurements, (2) changes in the shape of the basal reflector that prevented the reflections from being unequivocally matched, (3) too few high correlation values for a linear fit to be used to calculate the vertical strain rate.

For the remaining stations, we found a mean basal melt rate of $0.38 \pm 0.26 \mathrm{ma}^{-1}$ (mean + standard deviation; Fig. 2a) with a maximum of $1.13 \mathrm{ma}^{-1}$ at a location about $50 \mathrm{~km}$ downstream of the grounding line and freezing in the northernmost part of the central flow line (CFL). Of similar size but with different sign, the mean value of $\mathrm{D} H_{i} / \mathrm{D} t$ is $-0.38 \pm 0.32 \mathrm{ma}^{-1}$ (Fig. 2b), representing a thinning of the solid ice, whereas the mean value of $H_{i} \dot{\varepsilon}_{z z}\left(-0.01 \pm 0.20 \mathrm{ma}^{-1}\right)$ is close to zero (Fig. 2c).

We present the distribution of $a_{b}$ in Fig. 1b, as well as an along-flow profile (CFL) and five cross-sections (CSA-CSE) in Fig. 3. Seventy percent of the estimated basal melt rates range between 0 and $0.50 \mathrm{ma}^{-1}$. Higher melt rates were found for nine stations within $100 \mathrm{~km}$ of the grounding line at the CFL, CSA and CSB. All three stations with $a_{b}>1 \mathrm{ma}^{-1}$ are located in this part of the study area. The variation of $a_{b}$ along ice flow is weak and shows no clear trend of increasing melt towards 
https://doi.org/10.5194/tc-2021-230

Preprint. Discussion started: 27 August 2021

(c) Author(s) 2021. CC BY 4.0 License.

(c) (i)
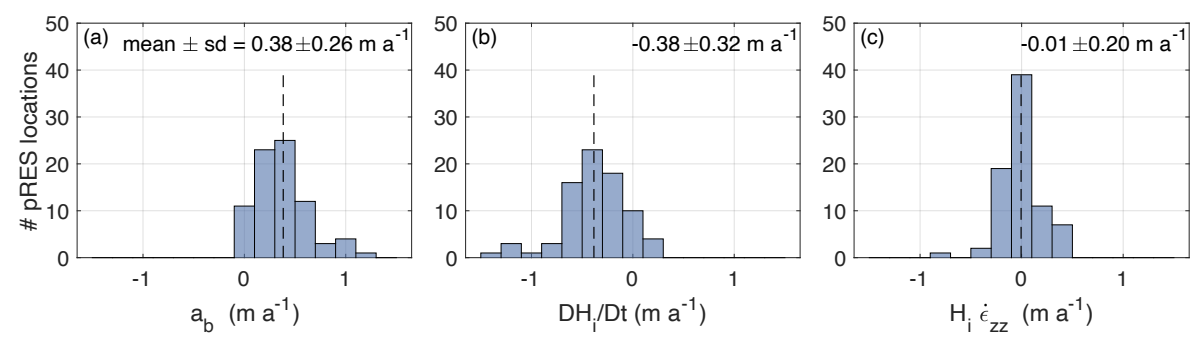

Figure 2. Distribution of pRES-derived results of (a) the basal melt rate $a_{b}$, (b) the change in solid-ice thickness $\mathrm{D} H_{i} / \mathrm{D} t$ and (c) the dynamic change in solid-ice thickness $H_{i} \dot{\varepsilon}_{z z}$. The numbers in the upper right corner state the mean value and the standard deviation (sd).

the grounding line, despite the increasing ice draft (Fig. 3a). In the direction across ice flow (Fig. 3b-f) the largest variations in $a_{b}$ appear in the two southernmost cross-sections (CSA, CSB). The northernmost cross-section, ranging from Berkner Island towards the inland ice (CSE), has a generally low $a_{b}$. Three stations, all at the northernmost part of CFL, indicate freezing. Apart from the southern part, higher basal melt rates, of up to $0.82 \mathrm{~m} \mathrm{a}^{-1}$, occur only at CSD. A large scale distribution of $a_{b}$ can also be influenced by changes in vertical gradients of the ice temperature. An ice shelf fed by a fast glacier typically contains a cold core as a result of ice advection, leading to larger vertical temperature gradients some distance from the grounding line. However, with melting over centuries, the ice temperature is more likely to approach a parabolic profile, with only moderate temperature gradients (Humbert, 2010). 

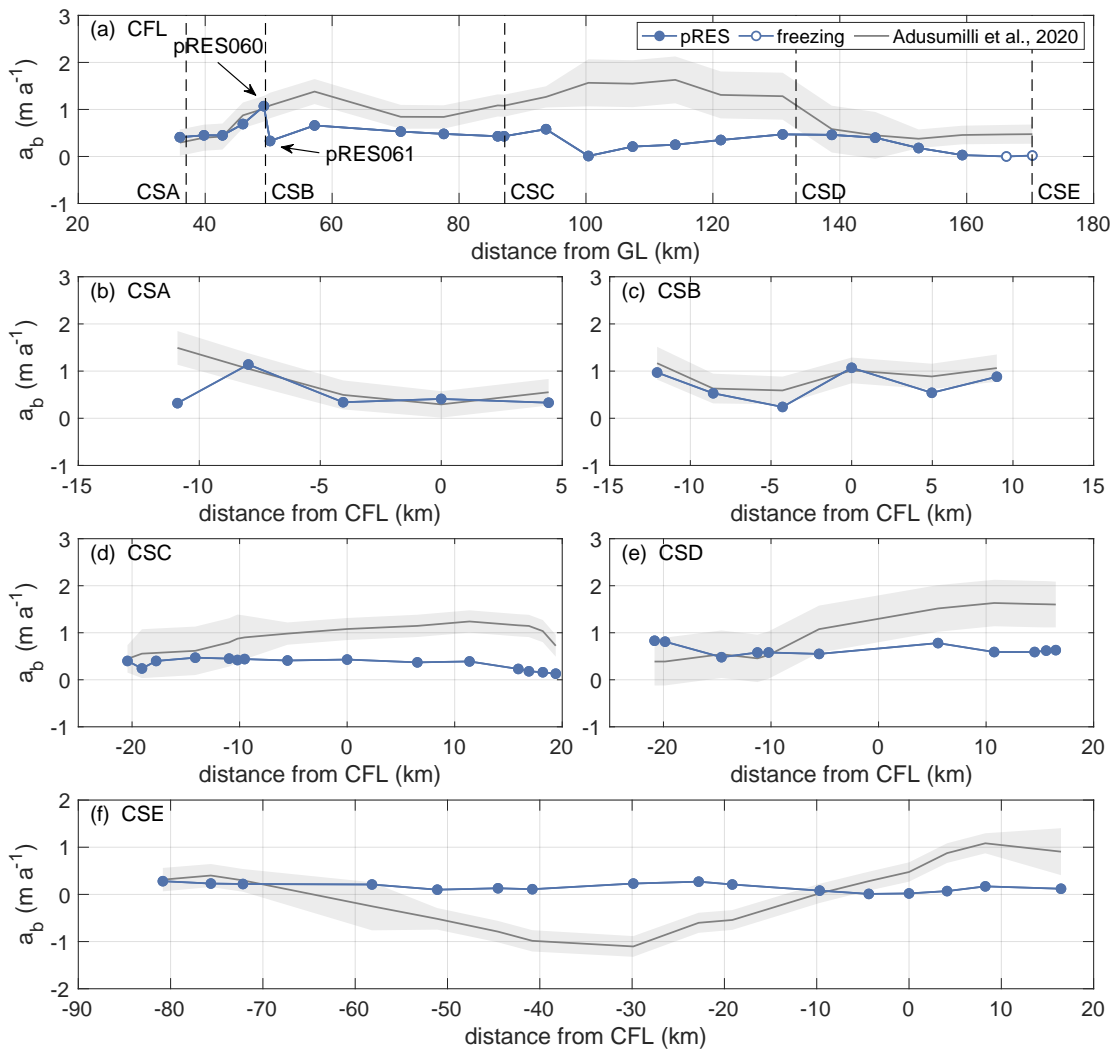

Figure 3. Variation of the basal melt rate (a) along the Central Flow Line (CFL) of Support Force Glacier's extension on the FIS and (b - f) the cross-sections CSA - CSE. Locations are shown in Fig. 1. pRES-derived values are shown in blue. The dark grey line represents remote sensing-derived melt rates and the light grey bounds display the uncertainty, both published by Adusumilli et al. (2020). Derived errors of the pRES measurements are too small to visualise. For CFL, the distance refers to the grounding line (GL) of Support Force Glacier and for all cross-sections to the CFL with positive distances on the eastern side. 
https://doi.org/10.5194/tc-2021-230

Preprint. Discussion started: 27 August 2021

(c) Author(s) 2021. CC BY 4.0 License.

(c) (i)

\subsection{Small scale spatial variability}

In order to assess the small scale spatial variability of the basal melt rates and hence the representativeness of measurements over large distances, we carried out 18 pRES measurements located, each within a 2-km of another measurement, at different locations across our survey area. In Fig. 4 we display the difference in melt rates $\left|\Delta a_{b}\right|$ between nearby station pairs as a function of the difference in ice-shelf draft $\left|\Delta h_{b}\right|$, derived from the BedMachine surface elevation (Morlighem, 2020; Morlighem et al., 2020), which gives and indication of large scale basal topography for the two locations. The basal melt rate of the higher melt rate station is indicated by colour, and the size of the dot represents the separation. For all but two $\left|\Delta H_{b}\right|$ is below $10 \mathrm{~m}$ and $\left|\Delta a_{b}\right|$ below $0.10 \mathrm{ma}^{-1}$, independent of the magnitude of $a_{b}$ or the distance between the measurements. The largest $\left|\Delta a_{b}\right|$ of $0.71 \mathrm{ma}^{-1}$ is coincident with $\left|\Delta h_{b}\right|$ of $10.5 \mathrm{~m}$ within a distance of $<1 \mathrm{~km}$ and was observed at locations pRES060 and pRES061 (Fig. 3 and Fig. B1). At location pRES060, we observed the higher melt rate as well as the larger draft of the two locations, which indicates an increased thermal forcing as a result of the higher basal pressure. Beside, the station with the second largest basal melt rate of $a_{b}>1.0 \mathrm{ma}^{-1}$ indicates a localised change in draft of $15.5 \mathrm{~m}$. Overall, this gives evidence that individual measurements are representative of a large area on the scale of many ice thicknesses and only minor variation due to the specific choice of the location of the measurement is to be expected for an ice base with suppressed basal topography. Airborne radar echograms (Fig. A1), recorded within NASA's Operation IceBridge (OIB) with a Center for Remote Sensing of Ice Sheets (CReSIS) Multi-channel Coherent Radar Depth Sounder (MCoRDS) in 2016 (Paden et al., 2014, updated 2019), show that this largely applies to the study area. For the most part, these radargrams show a smooth ice shelf base base with some slight variations of a few metres over several hundreds of metres, but without terrace structures. One exception is a basal channel in the west with a height of approx. $50 \mathrm{~m}$ (Fig. A1e,f). At three locations around this channel, pRES measurements have been performed (western part of CSC in Fig. 3d). These show low variability, with a basal melt rate $\sim 0.2 \mathrm{ma}^{-1}$ lower in the centre of the channel.

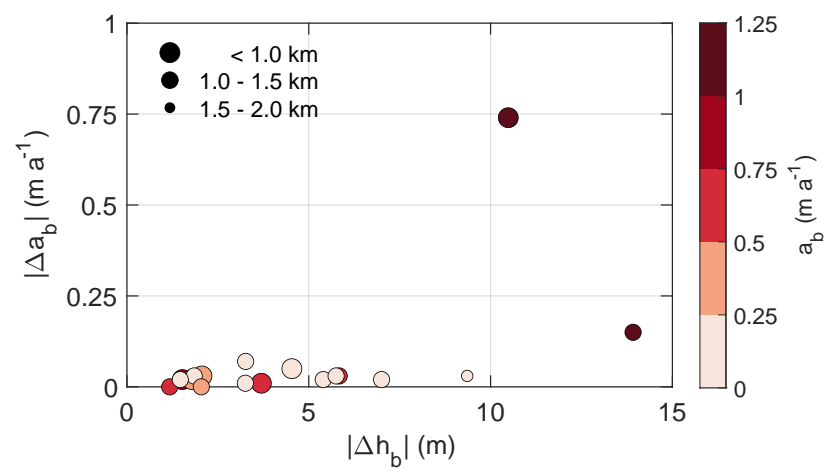

Figure 4. Small scale variability of basal melt rates and ice-shelf draft. Difference in basal melt rate $\left|\Delta a_{b}\right|$ in relation to ice-shelf draft $\left|\Delta h_{b}\right|$ for nearby stations (average distance: $1126 \pm 296 \mathrm{~m}$ ). The colour of each dot represents $a_{b}$ of the station with the larger basal melt rate and the size indicates the distance between both stations. 
https://doi.org/10.5194/tc-2021-230

Preprint. Discussion started: 27 August 2021

(c) Author(s) 2021. CC BY 4.0 License.

\section{(c) (i)}

\section{Comparison with remote sensing}

The analysis of remote sensing-derived basal melt rates is based on precisely measured elevation changes of the ice-shelf surface and on the correction of the surface mass balance, firn densification and dynamic change in ice thickness (e.g. Moholdt et al., 2015; Adusumilli et al., 2020). The dynamic change in ice thickness and thus the vertical strain rate is often derived from the divergence of a satellite sensor-derived surface velocity field.

We used the pRES-derived vertical strain rates to assess the reliability of strain rates derived from different remote sensing velocity fields. Satellite-derived melt rates at FIS from Rignot et al. (2013), Moholdt et al. (2015) and Adusumilli et al. (2020) were all based on the strain rates derived from the same early MEaSUREs velocities (Rignot et al., 2011; Scheuchl et al., 2012). However, this velocity field contained some significant data gaps in our study area that were not present in modern velocity fields such as the Landsat Ice Speed of Antarctica (LISA) product from which vertical strain rates were derived by Alley et al. (2018) or the newest MEaSUREs data set (Mouginot et al., 2019a, b). Instead of comparing the vertical strain rate itself, we compared the dynamic ice thickness change $\left(H_{i} \dot{\varepsilon}_{z z}\right)$ that was derived from the vertical strain rate and the solid-ice thickness. The result reveal a significant improvement over the last decade in the accuracy of the determination of vertical strain rates from remote sensing.

While the average deviation between the pRES-derived product and that from Moholdt et al. (2015) was $0.40 \pm 0.44 \mathrm{ma}^{-1}$ (mean \pm standard deviation; Fig. 5a,b and Fig. C1), there were much smaller deviations $\left(-0.01 \pm 0.35 \mathrm{~m} \mathrm{a}^{-1}\right)$ from the product of Alley et al. (2018) (Fig. 5c,d and Fig. C1). The comparison with the dynamic ice thickness that we calculated using the latest MEaSUREs data set (Mouginot et al., 2019a, b) also showed only minor deviations of $0.04 \pm 0.17 \mathrm{ma}^{-1}$ (Fig. 5e,f and Fig. C1). Here, similar to Moholdt et al. (2015), we applied a Gaussian filter with a $27 \times 27 \mathrm{~km}$ window to smooth the velocity data, and calculated the divergence to obtain the vertical strain rate. The comparison highlights the recent improvement in the estimation of velocity fields for more accurate calculation of dynamic ice thickness changes, and demonstrates good agreement between remote sensing-derived strain rates and those from in situ measurements.

Remote sensing-derived melt rates published by Rignot et al. (2013), Moholdt et al. (2015) and Adusumilli et al. (2020) suggested a similar pattern of melt rates: southeast of Berkner Island, a freezing regime in the west switches to a melting regime eastwards, with melting persisting towards the south to the Support Force Glacier. However, a data gap in the velocity field meant that no melt rates could be determined by Rignot et al. (2013) for a large part of our study area.

The comparison with the results from Adusumilli et al. (2020) reveals a broader distribution of the remote sensing-derived melt rate $\left(-1.1-1.6 \mathrm{~m} \mathrm{a}^{-1}\right)$ at the pRES locations with an average deviation from the pRES-derived values of $0.35 \pm 0.57 \mathrm{ma}^{-1}$ (Figs. 3 and 5g,h), which is of size similar to the deviation of the dynamic change in ice thickness. Another reason for the discrepancies can be the different measurement periods over which the basal melt rates were estimated: Adusumilli et al. (2020) shows that basal melt rates can vary at interannual timescales. In order to investigate whether different measurement periods contributed to the discrepancies between the results from the different methods, we compared the change in ice thickness $\mathrm{D} H_{i} / \mathrm{D} t$ (Eq. 1) after the correction for the surface mass balance and firn densification (Fig. C2). Some of the differences occur because Adusumilli et al. (2020) defines $H_{i}$ as the ice-shelf thickness in units of $\mathrm{m}$ of ice equivalent, which is slightly 
https://doi.org/10.5194/tc-2021-230

Preprint. Discussion started: 27 August 2021

(C) Author(s) 2021. CC BY 4.0 License.

(c) (i)

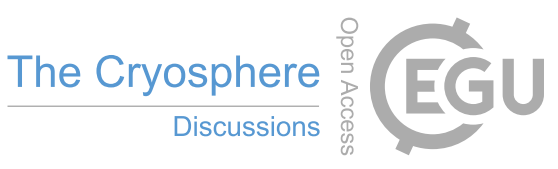

higher than the solid-ice thickness that we use for the pRES-based estimates. However, the comparison of $\mathrm{D} H_{i} / \mathrm{D} t$ shows a

good agreement, with an average difference of only $0.04 \pm 0.24 \mathrm{ma}^{-1}$ (Fig. 5i,j). Since variations in basal melt rate contribute to $\mathrm{D} H_{i} / \mathrm{D} t$ and this only shows slight differences, a temporal variation in basal melting can be excluded as the reason for the significant discrepancies that we find. Furthermore, this indicates that the techniques derive consistent changes in ice thickness from their initial measurements after applying the corrections for the surface mass balance and the firn densification, and that the large differences in basal melt rates result principally from differences in the strain rate, which can be improved by the use of modern surface velocity products. 

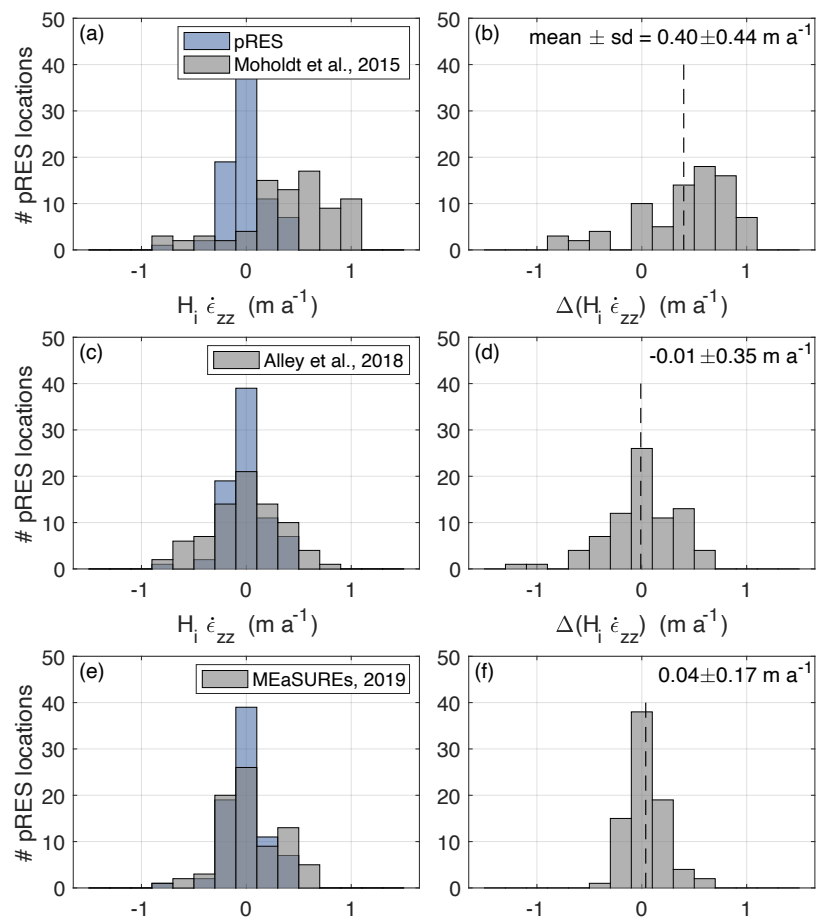

$\mathrm{H}_{\mathrm{i}} \dot{\epsilon}_{\mathrm{zz}}\left(\mathrm{m} \mathrm{a}^{-1}\right)$

$\Delta\left(\mathrm{H}_{\mathrm{i}} \dot{\epsilon}_{\mathrm{zz}}\right)\left(\mathrm{m} \mathrm{a}^{-1}\right)$
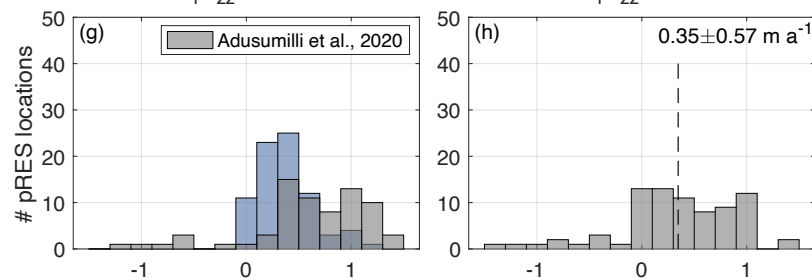

$a_{b}\left(m^{-1}\right)$

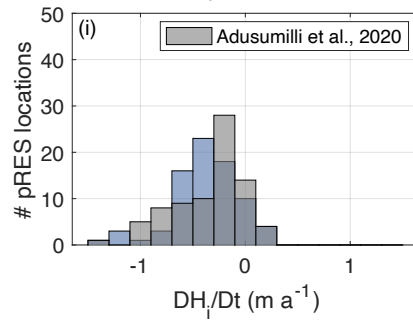

$\Delta \mathrm{a}_{\mathrm{b}}\left(\mathrm{m} \mathrm{a}^{-1}\right)$

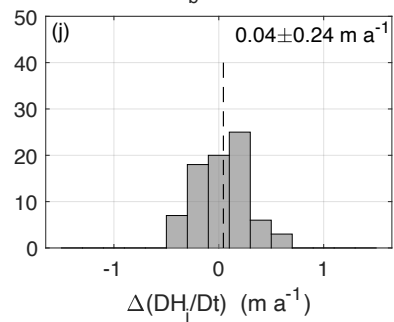

Figure 5. Comparison of remote sensing (grey) and pRES-derived (blue) results. The left column shows the distributions (a) of the dynamic change in ice thickness $H_{i} \dot{\varepsilon}_{z z}$ for the results published by Moholdt et al. (2015), (c) Alley et al. (2018) and (e) derived from the MEaSUREs product (Mouginot et al., 2019a, b), (g) of the basal melt rate $a_{b}$ and (i) of the change in ice thickness $\mathrm{D} H_{i} / \mathrm{D} t$, both in comparison with those from Adusumilli et al. (2020). The right column (b,d,f,h,j) shows the distribution of the deviation between remote sensing and pRES-derived values according to $(\mathrm{a}, \mathrm{c}, \mathrm{e}, \mathrm{g}, \mathrm{i})$. The numbers in the upper right corner state the mean value and the standard deviation (sd). Positive value refer to larger numbers derived from the remote sensing-based method. 
https://doi.org/10.5194/tc-2021-230

Preprint. Discussion started: 27 August 2021

(c) Author(s) 2021. CC BY 4.0 License.

(c) (i)

\section{Conclusions}

We have presented the first spatial distribution of basal melt rates in the southern Filchner Ice Shelf derived from repeated phase-sensitive radar measurements. In general the melt rates are moderate with maximum values in the centre of less than $1.13 \mathrm{ma}^{-1}$. We tested the representativeness of individual measurements by assessing the variability over short distances. Spatial variability in $a_{b}$ is low, with occasional outliers possibly linked to large basal gradients. This gives us confidence that a small number of widely spaced measurements accurately represent the large scale melt pattern. Temporal variability, however, is not captured. We find freezing at three locations - all in the northern part of the study area - but as yet we are unable to extract a rate from the radar data.

Our in situ measurements reveal that inaccuracies in the estimation of dynamic ice thickness change negatively affected recent remote sensing-derived melt rates at our study area at the Filchner Ice Shelf. A comparison with strain rates published by Alley et al. (2018) and with those derived from the newest MEaSUREs velocity field indicates that these inaccuracies can be overcome by using state-to-the-art velocity fields, in which data gaps could be closed. Our study demonstrates that satellitederived basal melt rates hold great promise, but care needs to be taken, as modelling of the future contribution of Antarctica to sea level rise is currently calibrated using such products (Jourdain et al., 2020). This highlights the need to obtain more data sets such as the one presented here, from across different ice shelves, and to conduct repeated field surveys to assess temporal variability.

Data availability. Raw data of the pRES measurements and derived melt rates (https://doi.pangaea.de/10.1594/PANGAEA.930735) are submitted to the World Data Center PANGAEA. Echograms recorded with a Center for Remote Sensing of Ice Sheets (CReSIS) Multichannel Coherent Radar Depth Sounder (MCoRDS) within NASA's Operation IceBridge (OIB) campaign in 2016 can be accessed at https://nsidc.org/data/IRMCR1B/versions/2 (Paden et al., 2014, updated 2019) (last access: 25 April 2021). Basal melt rate data published by Adusumilli et al. (2020) can be accessed at https://doi.org/10.6075/J04Q7SHT (last access: 04 March 2021). Ice-shelf divergence and thickness data published by Moholdt et al. (2015) can be accessed at https://doi.org/10.21334/npolar.2016.cae21585 (last access: 29 April 2021). Strain rate data published by Alley et al. (2018) can be accessed through open ftp by contacting the National Snow and Ice Data Center (NSIDC) (last access: 25 June 2021). MEaSUREs velocity product can be accessed at https://nsidc.org/data/nsidc-0754/versions/1 (Mouginot et al., 2019a) (last access: 13 April 2021). BedMachine Antarctica product can be accessed at http://nsidc.org/data/nsidc-0756 (Morlighem, 2020) (last access: 12 April 2021). 


\section{Appendix A: Airborne radar echograms}
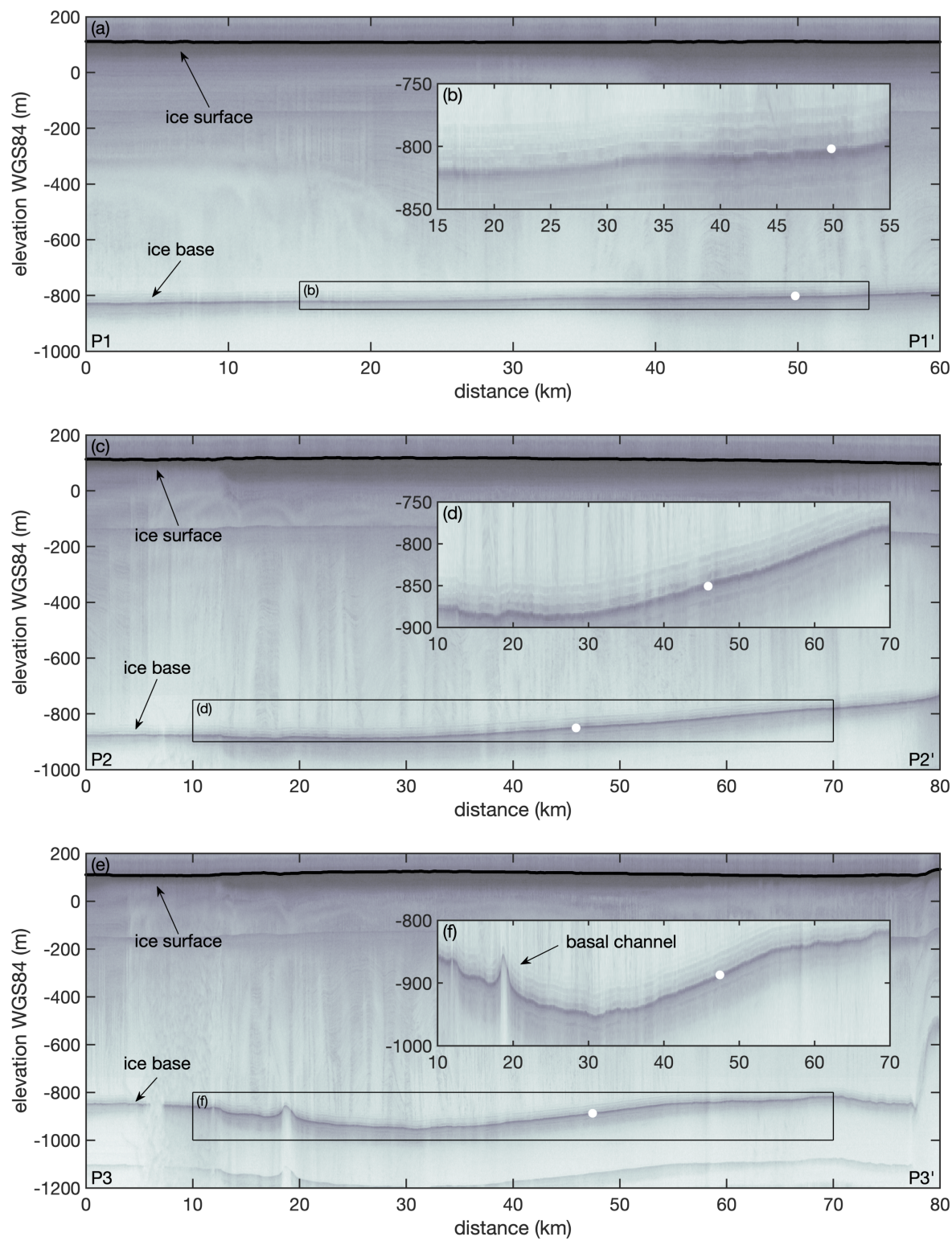

Figure A1. Airborne radar echograms (a) P1, (c) P2 and (e) P3 (location in Fig. 1), recorded with a Multi-channel Coherent Radar Depth Sounder (MCoRDS) as part of NASA's Operation IceBridge (OIB) campaign in 2016 (Paden et al., 2014, updated 2019; Arnold et al., 2020). (b,d,f) Insets showing enlarged basal section visualised by black box in (a), (c) and (e). The white dots mark the depth of the ice base derived from a near-by pRES measurement. 
https://doi.org/10.5194/tc-2021-230

Preprint. Discussion started: 27 August 2021

(c) Author(s) 2021. CC BY 4.0 License.

\section{Appendix B: pRES echograms}

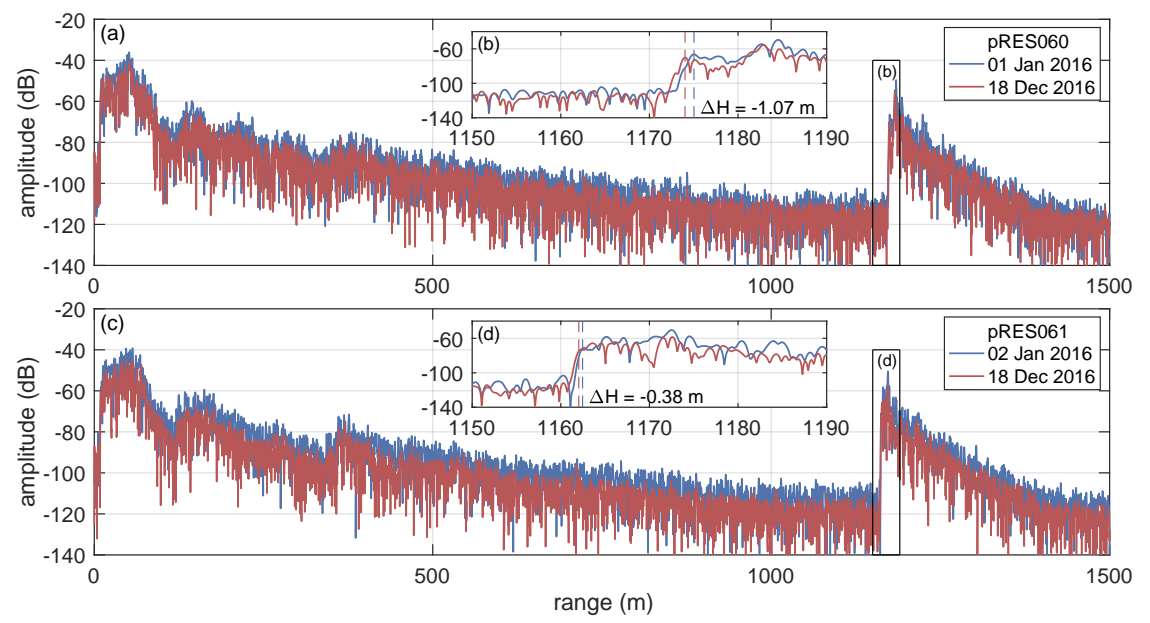

Figure B1. Amplitude profiles of first and repeated measurements at locations pRES060 (a,b) and pRES061 (c,d). Insets in (b) and (d) showing enlarged basal section, visualised by black boxes in (a) and (c). (b,d) Vertical dashed lines mark the ice thickness and $\Delta H$ the change in ice thickness between both visits. 
https://doi.org/10.5194/tc-2021-230

Preprint. Discussion started: 27 August 2021

(c) Author(s) 2021. CC BY 4.0 License.

\section{Appendix C: Comparison with remote sensing}
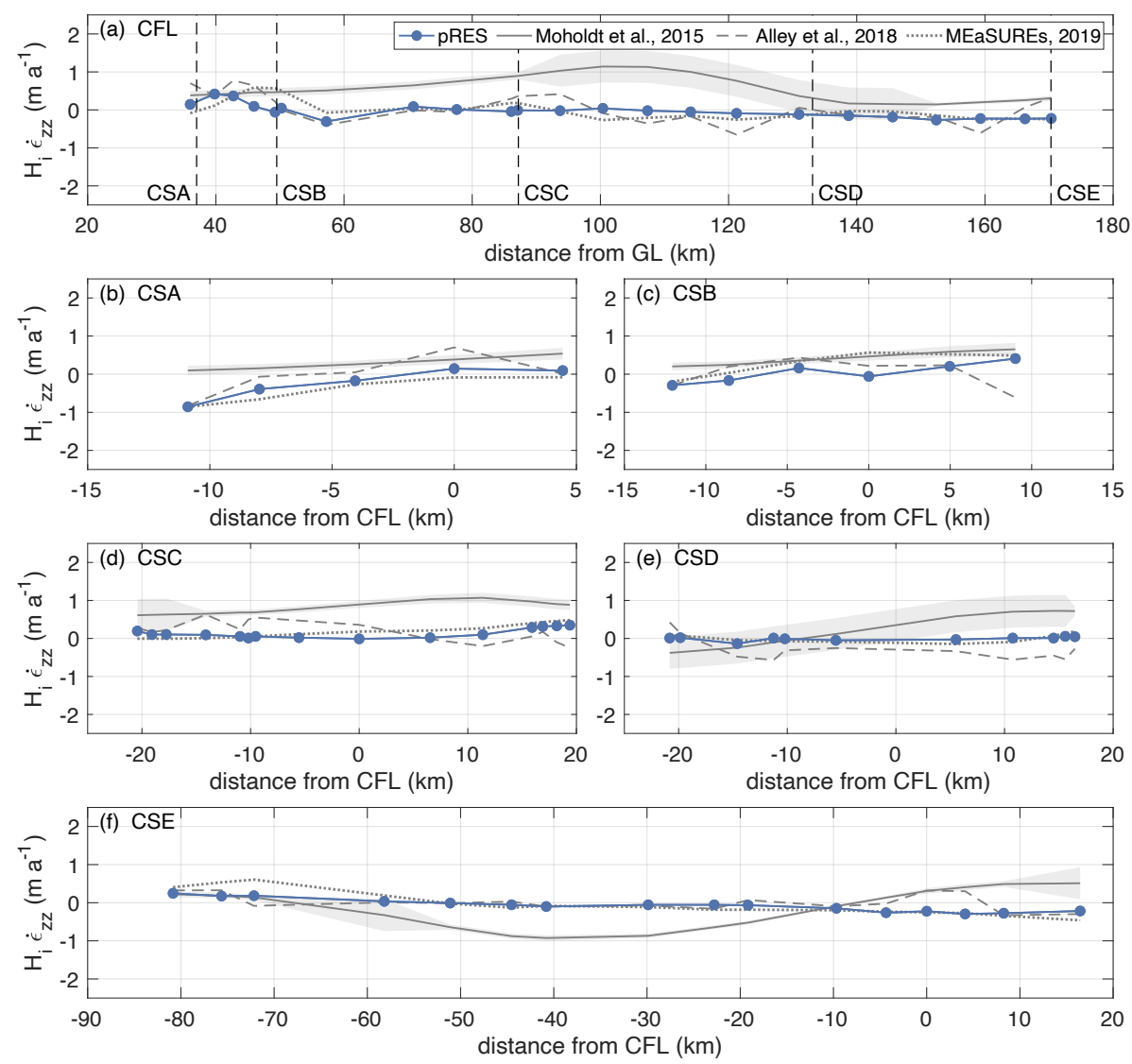

Figure C1. Variation of the dynamic ice thickness change $H_{i} \dot{\varepsilon}_{z z}$ (a) along the Central Flow Line (CFL) of Support Force Glacier's extension on the FIS and $(b-f)$ the cross-sections CSA - CSE. Locations are shown in Fig. 1. pRES-derived values are shown in blue. Remote sensing-derived values are represented by the solid grey line for results published by Moholdt et al. (2015), by a dashed line for results published by Alley et al. (2018), and by a dotted line for estimations derived from the MEaSUREs product (Mouginot et al., 2019a, b). The bounds of the results from Moholdt et al. (2015) display the uncertainties. Derived errors of the pRES measurements are too small to visualise. For CFL, the distance refers to the grounding line (GL) of Support Force Glacier and for all cross-sections to the CFL with positive distances on the eastern side. 

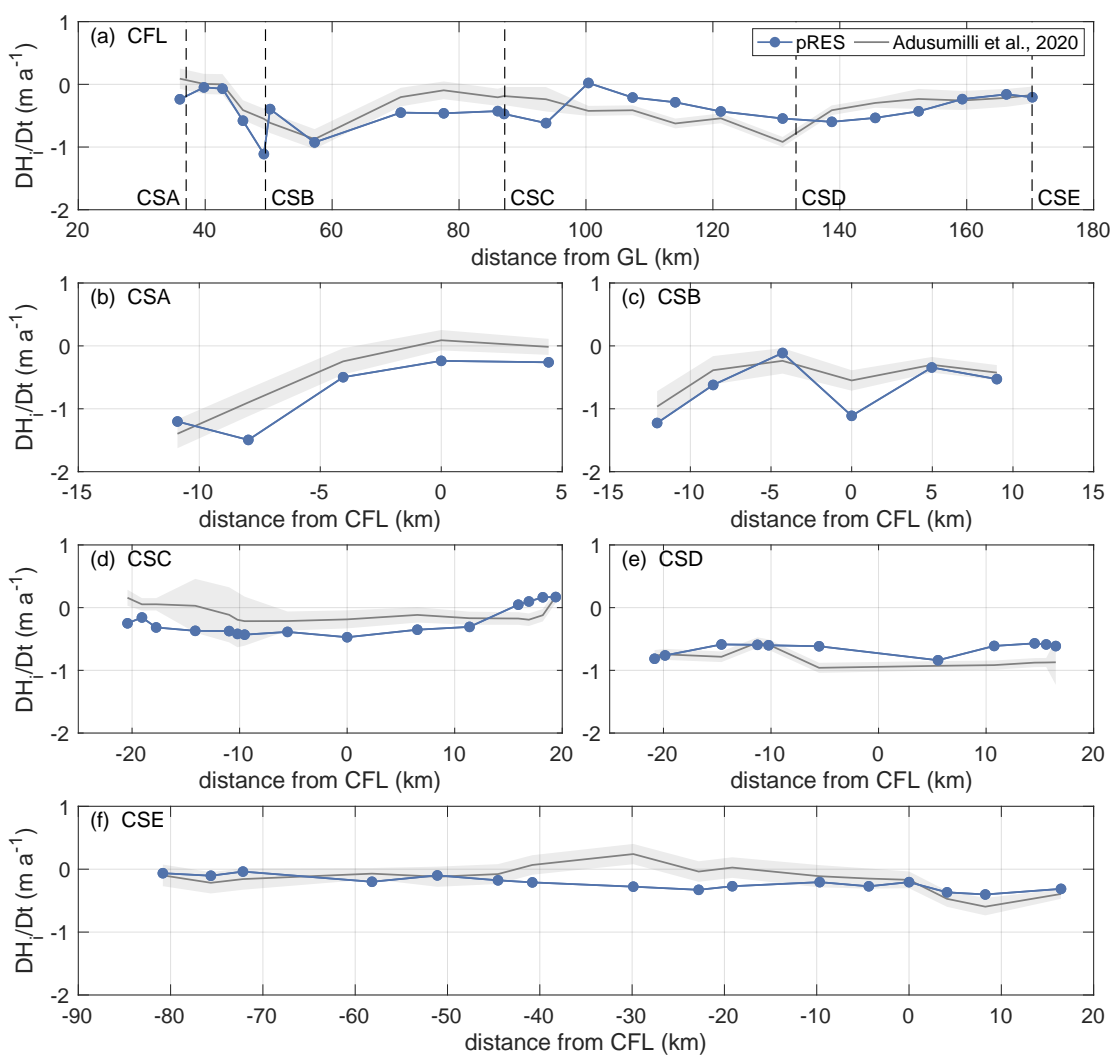

Figure C2. Variation of the ice thickness change $\mathrm{D} H_{i} / \mathrm{D} t$ (a) along the Central Flow Line (CFL) of Support Force Glacier's extension on the FIS and $(b-f)$ the cross-sections CSA - CSE. Locations are shown in Fig. 1. pRES-derived values are shown in blue. Remote sensingderived values are represented by the dark grey line for results published by Adusumilli et al. (2020). The light grey bounds display the uncertainties. Derived errors of the pRES measurements are too small to visualise. For CFL, the distance refers to the grounding line (GL) of Support Force Glacier and for all cross-sections to the CFL with positive distances on the eastern side. 
https://doi.org/10.5194/tc-2021-230

Preprint. Discussion started: 27 August 2021

(c) Author(s) 2021. CC BY 4.0 License.

(c) (i)

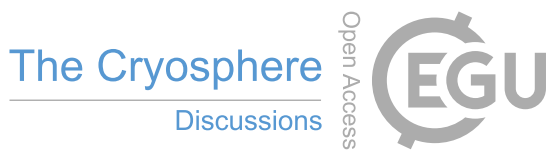

Author contributions. OZ processed the data. OZ and AH analysed the basal melt rates and wrote the manuscript together with KWN. AH has designed the study and conducted the field study together with DS. KWN supported the field study and contributed to melt rate analysis and its discussion together with HFJC and AH. CLS wrote main parts of the MATLAB routines and supported data analysing.

Competing interests. The authors declare that they have no conflict of interest.

205 Acknowledgements. This work was funded by the AWI strategy fund project FISP. Support for this work came from the UK Natural Environment Research Council large grant "Ice shelves in a warming world: Filchner Ice Shelf System" (NE/L013770/1). We acknowledge provision of data products by Susheel Adusumilli (Scripps Institution of Oceanography, University of California San Diego, La Jolla, CA, USA), that have been published in Adusumilli et al. (2020). We want to thank Graham Niven and Bradley Morrell for their support in the field. We are grateful for discussions with Veit Helm and Niklas Neckel (AWI) on remote sensing-derived vertical strain rates and our results. 
https://doi.org/10.5194/tc-2021-230

Preprint. Discussion started: 27 August 2021

(c) Author(s) 2021. CC BY 4.0 License.

(c) (i)

\section{References}

Adusumilli, S., Fricker, H. A., Medley, B., Padman, L., and Siegfried, M. R.: Interannual variations in meltwater input to the Southern Ocean from Antarctic ice shelves, Nature Geoscience, 13, 616-620, https://doi.org/10.1038/s41561-020-0616-z, 2020.

Alley, K. E., Scambos, T. A., Anderson, R. S., Rajaram, H., Pope, A., and Haran, T. M.: Continent-wide estimates of Antarctic strain rates from Landsat 8-derived velocity grids, Journal of Glaciology, 64, 321-332, https://doi.org/10.1017/jog.2018.23, 2018.

Arnold, E., Leuschen, C., Rodriguez-Morales, F., Li, J., Paden, J., Hale, R., and Keshmiri, S.: CReSIS airborne radars and platforms for ice and snow sounding, Annals of Glaciology, 61, 58-67, https://doi.org/10.1017/aog.2019.37, 2020.

Berger, S., Drews, R., Helm, V., Sun, S., and Pattyn, F.: Detecting high spatial variability of ice shelf basal mass balance, Roi Baudouin Ice Shelf, Antarctica, The Cryosphere, 11, 2675-2690, https://doi.org/10.5194/tc-11-2675-2017, 2017.

Brennan, P. V., Nicholls, K., Lok, L. B., and Corr, H.: Phase-sensitive FMCW radar system for high-precision Antarctic ice shelf profile monitoring, IET Radar, Sonar \& Navigation, 8, 776-786, https://doi.org/10.1049/iet-rsn.2013.0053, 2014.

Bull, C. Y. S., Jenkins, A., Jourdain, N. C., Vaňková, I., Holland, P. R., Mathiot, P., Hausmann, U., and Sallée, J.-B.: Remote Control of Filchner-Ronne Ice Shelf Melt Rates by the Antarctic Slope Current, Journal of Geophysical Research: Oceans, 126, e2020JC016 550, https://doi.org/10.1029/2020JC016550, 2021.

Corr, H. F. J., Jenkins, A., Nicholls, K. W., and Doake, C. S. M.: Precise measurement of changes in ice-shelf thickness by phase-sensitive radar to determine basal melt rates, Geophysical Research Letters, 29, 73-1-74-4, https://doi.org/10.1029/2001GL014618, 2002.

Hattermann, T., Nicholls, K. W., Hellmer, H. H., Davis, P. E. D., Janout, M. A., Østerhus, S., Schlosser, E., Rohardt, G., and Kanzow, T.: Observed interannual changes beneath Filchner-Ronne Ice Shelf linked to large-scale atmospheric circulation, Nature Communications, 12, 2961, https://doi.org/10.1038/s41467-021-23131-x, 2021.

Hellmer, H. H., Kauker, F., Timmermann, R., Determann, J., and Rae, J.: Twenty-first-century warming of a large Antarctic ice-shelf cavity by a redirected coastal current, Nature, 485, 225-228, https://doi.org/10.1038/nature11064, 2012.

Herron, M. M. and Langway, C. C.: Firn densification: An empirical model, Journal of Glaciology, 25, 373-385, 1980.

Humbert, A.: The temperature regime of Fimbulisen, Antarctica, Annals of Glaciology, 51, 56-64, https://doi.org/10.3189/172756410791392673, 2010.

Jenkins, A., Corr, H. F. J., Nicholls, K. W., Stewart, C. L., and Doake, C. S. M.: Interactions between ice and ocean observed with phase-sensitive radar near an Antarctic ice-shelf grounding line, Journal of Glaciology, 52, 325-346, https://doi.org/10.3189/172756506781828502, 2006.

Jourdain, N. C., Asay-Davis, X., Hattermann, T., Straneo, F., Seroussi, H., Little, C. M., and Nowicki, S.: A protocol for calculating basal melt rates in the ISMIP6 Antarctic ice sheet projections, The Cryosphere, 14, 3111-3134, https://doi.org/10.5194/tc-14-3111-2020, 2020.

Marsh, O. J., Fricker, H. A., Siegfried, M. R., Christianson, K., Nicholls, K. W., Corr, H. F., and Catania, G.: High basal melting forming a channel at the grounding line of Ross Ice Shelf, Antarctica, Geophysical Research Letters, 43, 250-255, https://doi.org/10.1002/2015GL066612, 2016.

Moholdt, G., Padman, L., and Fricker, H. A.: Basal mass budget of Ross and Filchner-Ronne ice shelves, Antarctica, derived from Lagrangian analysis of ICESat altimetry, Journal of Geophysical Research: Earth Surface, 119, 2361-2380, https://doi.org/10.1002/2014JF003171, 2015.

Morlighem, M.: MEaSUREs BedMachine Antarctica, Version 2. Boulder, Colorado USA. NASA National Snow and Ice Data Center Distributed Active Archive Center, Accessed 12 April 2021, https://doi.org/10.5067/E1QL9HFQ7A8M, 2020. 
https://doi.org/10.5194/tc-2021-230

Preprint. Discussion started: 27 August 2021

(c) Author(s) 2021. CC BY 4.0 License.

(c) (i)

Morlighem, M., Rignot, E., Binder, T., Blankenship, D., Drews, R., Eagles, G., Eisen, O., Ferraccioli, F., Forsberg, R., Fretwell, P., Goel, V., Greenbaum, J. S., Gudmundsson, H., Guo, J., Helm, V., Hofstede, C., Howat, I., Humbert, A., Jokat, W., Karlsson, N. B., Lee, W. S., Matsuoka, K., Millan, R., Mouginot, J., Paden, J., Pattyn, F., Roberts, J., Rosier, S., Ruppel, A., Seroussi, H., Smith, E. C., Steinhage, D., Sun, B., Broeke, M. R. v. d., Ommen, T. D. v., Wessem, M. v., and Young, D. A.: Deep glacial troughs and stabilizing ridges unveiled beneath the margins of the Antarctic ice sheet, Nature Geoscience, 13, 132-137, https://doi.org/10.1038/s41561-019-0510-8, 2020.

Mouginot, J., Rignot, E., and Scheuchl, B.: MEaSUREs Phase-Based Antarctica Ice Velocity Map, Version 1. Boulder, Colorado USA. NASA National Snow and Ice Data Center Distributed Active Archive Center, Accessed 13 April 2021, https://doi.org/10.5067/PZ3NJ5RXRH10, $2019 \mathrm{a}$.

Mouginot, J., Rignot, E., and Scheuchl, B.: Continent-Wide, Interferometric SAR Phase, Mapping of Antarctic Ice Velocity, Geophysical Research Letters, 46, 9710-9718, https://doi.org/10.1029/2019GL083826, 2019b.

Nicholls, K. W., Corr, H. F., Stewart, C. L., Lok, L. B., Brennan, P. V., and Vaughan, D. G.: A ground-based radar for measuring vertical strain rates and time-varying basal melt rates in ice sheets and shelves, Journal of Glaciology, 61, 1079-1087, https://doi.org/10.3189/2015jog15j073, 2015.

Paden, J., Li, J., Leuschen, C., Rodriguez-Morales, F., and Hale, R.: IceBridge MCoRDS L1B Geolocated Radar Echo Strength Profiles, Version 2. IRMCR1B, Boulder, Colorado USA. NASA National Snow and Ice Data Center Distributed Active Archive Center, https://doi.org/10.5067/90S1XZRBAX5N, accessed 25 April 2021, 2014, updated 2019.

Rignot, E., Mouginot, J., and Scheuchl, B.: Ice Flow of the Antarctic Ice Sheet, Science, 333, 1427-1430, https://doi.org/10.1126/science.1208336, 2011.

Rignot, E., Jacobs, S., Mouginot, J., and Scheuchl, B.: Ice-Shelf Melting Around Antarctica, Science, 341, 266-270, https://doi.org/10.1126/science.1235798, 2013.

Rignot, E., Mouginot, J., Scheuchl, B., van den Broeke, M., van Wessem, M. J., and Morlighem, M.: Four decades of Antarctic Ice Sheet mass balance from 1979-2017, Proceedings of the National Academy of Sciences, 116, 1095-1103, https://doi.org/10.1073/pnas.1812883116, 2019.

Scheuchl, B., Mouginot, J., and Rignot, E.: Ice velocity changes in the Ross and Ronne sectors observed using satellite radar data from 1997 and 2009, The Cryosphere, 6, 1019-1030, https://doi.org/10.5194/tc-6-1019-2012, 2012.

Schoof, C.: Marine ice sheet stability, Journal of Fluid Mechanics, 698, 62-72, https://doi.org/10.1017/jfm.2012.43, 2012.

Seroussi, H., Nowicki, S., Payne, A. J., Goelzer, H., Lipscomb, W. H., Abe-Ouchi, A., Agosta, C., Albrecht, T., Asay-Davis, X., Barthel, A., Calov, R., Cullather, R., Dumas, C., Galton-Fenzi, B. K., Gladstone, R., Golledge, N. R., Gregory, J. M., Greve, R., Hattermann, T., Hoffman, M. J., Humbert, A., Huybrechts, P., Jourdain, N. C., Kleiner, T., Larour, E., Leguy, G. R., Lowry, D. P., Little, C. M., Morlighem, M., Pattyn, F., Pelle, T., Price, S. F., Quiquet, A., Reese, R., Schlegel, N.-J., Shepherd, A., Simon, E., Smith, R. S., Straneo, F., Sun, S., Trusel, L. D., Van Breedam, J., van de Wal, R. S. W., Winkelmann, R., Zhao, C., Zhang, T., and Zwinger, T.: ISMIP6 Antarctica: a multimodel ensemble of the Antarctic ice sheet evolution over the 21st century, The Cryosphere, 14, 3033-3070, https://doi.org/10.5194/tc-143033-2020, 2020.

Stewart, C. L., Christoffersen, P., Nicholls, K. W., Williams, M. J., and Dowdeswell, J. A.: Basal melting of Ross Ice Shelf from solar heat absorption in an ice-front polynya, Nature Geoscience, 12, 435, https://doi.org/10.1038/s41561-019-0356-0, 2019.

van Wessem, J. M., Reijmer, C. H., Morlighem, M., Mouginot, J., Rignot, E., Medley, B., Joughin, I., Wouters, B., Depoorter, M. A., Bamber, J. L., Lenaerts, J. T. M., van de Berg, W. J., van den Broeke, M. R., and van Meijgaard, E.: Improved representation of East Antarctic sur- 
https://doi.org/10.5194/tc-2021-230

Preprint. Discussion started: 27 August 2021

(C) Author(s) 2021. CC BY 4.0 License.

(c) (1)

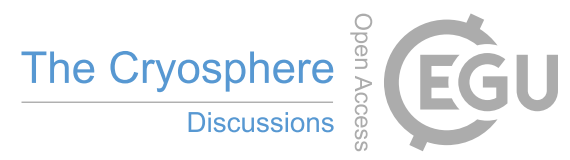

face mass balance in a regional atmospheric climate model, Journal of Glaciology, 60, 761-770, https://doi.org/10.3189/2014JoG14J051,

2014.

Vaňková, I., Nicholls, K. W., Corr, H. F., Makinson, K., and Brennan, P. V.: Observations of tidal melt and vertical strain at the Filchner-Ronne Ice Shelf, Antarctica, Journal of Geophysical Research: Earth Surface, 125, e2019JF005 280, https://doi.org/10.1029/2019JF005280, 2020.

Washam, P., Nicholls, K. W., Münchow, A., and Padman, L.: Summer surface melt thins Petermann Gletscher Ice Shelf by enhancing channelized basal melt, Journal of Glaciology, 65, 662-674, https://doi.org/10.1017/jog.2019.43, 2019. 